\title{
Drivers of risk perceptions about the invasive non-native plant Japanese knotweed in domestic gardens
}

\author{
Beth S. Robinson · Richard Inger · Kevin J. Gaston
}

Received: 11 May 2016/Accepted: 26 June 2017/Published online: 4 July 2017

(C) The Author(s) 2017. This article is an open access publication

\begin{abstract}
How people perceive risks posed by invasive non-native plants (INNP) can influence attitudes and consequently likely influence behavioural decisions. Although some drivers of risk perception for INNP have been identified, research has not determined those for INNP in domestic gardens. This is concerning as domestic gardens are where people most commonly encounter INNP, and where impacts can be particularly acute. Using a survey approach, this study determined the drivers of perceptions of risk of INNP in domestic gardens and which risks most concern people. Japanese knotweed Fallopia japonica, in Cornwall, UK, where it is a problematic INNP in domestic gardens, was used as a case study. Possible drivers of risk were chosen a priori based on variables previously found to be important for environmental risks. Participants perceived Japanese knotweed to be less frequent on domestic property in Cornwall if their occupation involved the housing market, if they had not had Japanese knotweed in their own garden, if they did not know of Japanese knotweed within $5 \mathrm{~km}$ of their home, or if they were educated to degree level. Participants who thought that the consequences of
\end{abstract}

Electronic supplementary material The online version of this article (doi:10.1007/s10530-017-1495-0) contains supplementary material, which is available to authorized users.

B. S. Robinson $(\bowtie) \cdot$ R. Inger · K. J. Gaston Environment and Sustainability Institute, University of Exeter, Penryn, Cornwall TR10 9FE, UK

e-mail: b.robinson@exeter.ac.uk
Japanese knotweed being present on domestic property could be more severe had occupations that involved the housing market, knew of Japanese knotweed within $5 \mathrm{~km}$ of their home, or were older. Although concern about the damage Japanese knotweed could do to the structure of a property was reported as the second highest motivation to control it by the majority of participants, the perception of threat from this risk was rated as relatively low. The results of this study have implications for policy, risk communication, and garden management decisions. For example, there is a need for policy that provides support and resources for people to manage INNP in their local area. To reduce the impact and spread of INNP we highlight the need for clear and accurate risk communication within discourse about this issue. The drivers identified in this study could be used to target awareness campaigns to limit the development of over- or under-inflated risk perceptions.

Keywords Domestic gardens - Fallopia japonica . Invasive plants · Japanese knotweed · Non-native plants $\cdot$ Risk perception

\section{Introduction}

Invasive non-native plants (INNP) are a significant driver, as well as a product of, global environmental change (Simberloff et al. 2013; Blackburn et al. 2014). 
INNP often pose major risks to the environment, ecosystem services and human well-being (Pejchar and Mooney 2009; Vilà et al. 2011; Jeschke et al. 2014). These risks are likely to be greatly exacerbated as overall anthropogenic pressures on the natural environment increase (Banks et al. 2014).

The risks posed by INNP are managed and mitigated by people. However, the details and extent of the perception of such risks are inherently highly variable between individuals (Slimak and Dietz 2006; Vanderhoeven et al. 2011; Gozlan et al. 2013), are largely species dependent (Sharp et al. 2011; Gozlan et al. 2013; Verbrugge et al. 2013), and do not always correlate with actual ecological risk (Andreu et al. 2009; Gozlan et al. 2013). People are generally poor at assessing risks (Wachinger et al. 2013), frequently exaggerating some whilst downplaying others (Clayton and Myers 2009). The processes that lead to development of perceptions of risk are complex (Slovic 1999). Whilst there is debate over the levels of rationality and subjectivity involved (Slovic 1999; Sjoberg 1999), certain drivers have recurrently been found to influence their development (Slimak and Dietz 2006). These include, for example, direct or indirect experience of a risk, proximity to the risk, and certain socio-demographic variables (e.g. age, education and gender; Kasperson et al. 1988; Flynn et al. 1994; Gustafson 1998; Slovic 1999; Carlton and Jacobson 2013; Wachinger et al. 2013).

How an individual perceives the risks of a specific INNP is central to determining their attitudes towards it, and subsequently their behaviour (Fischer and van der Wal 2007; Estévez et al. 2014). For example, divergent perceptions about the risks from INNP might result in conflict over management approaches, priorities, or even in opinions regarding whether they should be controlled at all (McDaniels et al. 1997; Estévez et al. 2014). In domestic gardens, where the management of INNP is largely the responsibility of the owner or tenant of a given garden (Qvenild et al. 2014), the consequences of variation in perceptions of risks of INNP are likely to result in spatial heterogeneity in how INNP are managed therein.

INNP in domestic gardens can pose serious ecological risks, both within the garden and, if they escape, in the wider environment (Groves et al. 2005; Sullivan et al. 2005). Furthermore, the risks posed by INNP in domestic gardens can result in large economic costs (McDermott et al. 2013), and can cause high levels of anxiety (Eskridge and Alderman 2010). Mismanagement of INNP in domestic gardens could increase the ecological and socio-economic impacts INNP have, encourage their spread (van Heezik et al. 2013), and be detrimental to the wellbeing, biodiversity and ecosystem services that gardens can provide. The wellbeing benefits gardens can deliver, such as providing a space for leisure and social activities (Bhatti and Church 2004), opportunities to connect with nature (Restall and Conrad 2015) and opportunities to gain ecological knowledge and skills (Barthel et al. 2010), will only become more important in an increasingly urbanised world (UN 2010). Similarly, the significant contribution domestic gardens make to urban ecosystem functioning and habitat connectivity in many westernised countries, due to the large proportion of urban land they cover, will also become increasingly important as urbanisation increases. For example, private gardens account for over $20 \%$ of land cover in some UK cities (Loram et al. 2007) and over $35 \%$ in New Zealand (Mathieu et al. 2007).

Research into INNP in domestic gardens is relatively scarce (Qvenild et al. 2014). This is especially true of studies considering the perceptions of INNP. Studies that have examined perceptions of INNP in domestic gardens have largely focused on their categorisation as native or non-native, and their perceived level of invasiveness (e.g. Zagorski et al. 2004; Qvenild et al. 2014), rather than the perception of risks that specific INNP pose.

In this paper, we employ a survey approach to determine the drivers of people's perception of the risks from INNP in domestic gardens, and which risks concern them most. The variables selected for the survey as potentially influencing perception of risk of INNP were chosen a priori based on knowledge of how they influence perceptions of other environmental risks. The results of this analysis help to reveal whether and why people might develop over- or under- inflated perceptions of risk. Furthermore, identifying drivers of perception of risk can assist in informing the design and targeting of risk communication, education and awareness strategies to reduce the ecological and socio-economic impacts of INNP. We use Japanese knotweed Fallopia japonica in the UK as a case study, as it exemplifies many of the risks surrounding INNP in domestic gardens, as well as having a number of additional risks when present on domestic property (e.g. it might devalue property; van 
Ham et al. 2013). Data were collected in Cornwall, a county in the southwest of the UK.

\section{Method}

Japanese knotweed

Introduced as a desirable garden plant in c.1850 (Shaw et al. 2011), Japanese knotweed has since become widespread in much of the UK (Engler et al. 2011); it is prevalent in the study region, Cornwall (present in $38.6 \%(\mathrm{n}=1517)$ of $39321 \times 1 \mathrm{~km}$ grid-cells covering the county; Cornwall Council pers. comm.; NBN 2015). The ecological traits of Japanese knotweed make it a particularly difficult INNP to control or eradicate. For example, it can regrow from a small fragment of rhizome (Colleran and Goodall 2014), it can grow fast (Beerling et al. 1994), and its roots extend far both vertically and horizontally (EA 2013). Ecological risks of Japanese knotweed include outcompeting native plants, directly for light and water and indirectly via alleopathy (Dommanget et al. 2014), and changing habitat structure for animals (Engler et al. 2011). On domestic property it can have a number of socio-economic risks. For example, it can cause undesirable changes to gardens by outcompeting other plants, it can have a negative aesthetic impact, and be costly to eradicate or control. If it is present in a garden, or even on nearby land, it might reduce the value of the property/land and might cause complications in obtaining a mortgage (RICS 2012; Taylor et al. 2013; van Ham et al. 2013). If it spreads from a garden to adjacent land it could result in legal proceedings by neighbours as it is considered a 'private nuisance' (Payne and Hoxley 2012). More recent legislation grants environmental agencies (e.g. Environment Agency) the authority to access the property to control it if required, and failure to comply could result in prosecution (Home Office 2014; House of Lords 2014).

Selection of variables potentially influencing perception of risk

We used drivers demonstrated as influencing perceptions of a broad range of environmental risks (e.g. flooding, earthquakes, volcanic eruptions and landslides) to inform those included in the survey that might influence the perception of risk of Japanese knotweed in domestic gardens (Table 1); not all of these variables consistently predict perceptions of risk. The perception of risk of Japanese knotweed in domestic gardens was measured as perceived (a) frequency of this plant and (b) severity of impacts (Kasperson et al. 1988).

\section{Direct experience}

Research suggests that direct experience of a risk will likely result in greater clarity, persistence and strength of perception of that risk compared with indirect experience (Whitmarsh 2008). Here we consider two types of direct experience:

1. Direct professional experience If participants' have or had an occupation where they are more likely to encounter Japanese knotweed. In this study we define two possible categories of such professions: (1) working in the housing market sector, including as estate agents, solicitors, architects, building surveyors or mortgage advisors; and (2) work involving ecology, including as ecological consultants, working for a UK environmental/conservation organisation (e.g. Natural England or National Trust), or as an academic whose research involves ecology. All other occupations were grouped as 'other'.

2. Direct domestic experience If participants have or have had Japanese knotweed in the garden of a property they have owned or rented, or on land they have managed.

\section{Indirect experience}

When people do not have direct experience of an event they base their perceptions of risk on information from secondary sources, for example friends, family or media (Kasperson et al. 1988). Mass media has been found to be the most common way of obtaining information on INNP (McNeely 2001). Theoretical and empirical research suggests that when people gain information about a risk from secondary sources, and combine it with perceptions of closely related risks, it can result in social amplification of that risk (Pidgeon et al. 2003). Resulting behavioral responses can have secondary social and economic consequences (Renn et al. 1992). Determining whether survey participants 
Table 1 Summary of variables chosen a priori that might be influencing perception of risk of INNP on domestic property

\begin{tabular}{|c|c|}
\hline Variable & Levels of variable \\
\hline \multicolumn{2}{|l|}{ Direct experience } \\
\hline 1. Direct professional experience & $\begin{array}{l}\text { If occupation involves the housing market } \\
\text { If occupation involves ecology } \\
\text { Occupation = other }\end{array}$ \\
\hline 2. Direct domestic experience & $\begin{array}{l}\text { False } \\
\text { True }\end{array}$ \\
\hline \multicolumn{2}{|l|}{ Indirect experience } \\
\hline 1. Heard only from mass media & $\begin{array}{l}\text { False } \\
\text { True }\end{array}$ \\
\hline \multicolumn{2}{|l|}{ Proximity to risk } \\
\hline 1. Geographical: If know of Japanese knotweed within $5 \mathrm{~km}$ of home & $\begin{array}{l}\text { False } \\
\text { True }\end{array}$ \\
\hline 2. Liability: If own property & $\begin{array}{l}\text { False } \\
\text { True }\end{array}$ \\
\hline \multicolumn{2}{|l|}{ Socio-demographics } \\
\hline 1. Gender & $\begin{array}{l}\text { Female } \\
\text { Male }\end{array}$ \\
\hline 2. Level of education & $\begin{array}{l}\text { 1: 'O' level, GCSE, or equivalent or less } \\
\text { 2: 'A' Level, AS Level, or equivalent } \\
\text { 3: Further education or vocational training } \\
\text { 4: First degree or higher }\end{array}$ \\
\hline 3. Age category & $\begin{array}{l}18-29 \\
30-39 \\
40-49 \\
50-59 \\
60+\end{array}$ \\
\hline
\end{tabular}

who only receive information about Japanese knotweed via the mass media have under- or over-inflated perceptions of risk would help understand if its media portrayal is contributing to social amplification of risk. We define mass media as TV, radio and newspapers.

\section{Proximity to risk}

If an individual is closer to a risk, either geographically, or in a way that increases their liability to the impacts, the consequences will likely appear greater; in our survey we considered both of these:

1. Geographically closer This was measured in terms of whether participants know of Japanese knotweed within $5 \mathrm{~km}$ of home, either in a garden or on other land.
2. Increased liability One way in which proximity to the liability of certain risks can increase, and that has been proven in some studies to influence perception of risk, is by owning rather than renting property (Burningham et al. 2008; Wachinger et al. 2013). The assumption is that if someone owns property they might be more concerned about certain environmental risks as they are usually responsible for resulting economic costs.

\section{Socio-demographics}

We selected three socio-demographic variables that are easily and accurately measurable. 
1. Gender the socio-demographic variable perhaps most commonly examined as a driver in perception of risk is gender (Slovic 1999), with multiple studies finding that women generally perceive risks as more problematic than do men (Flynn et al. 1994; Gustafson, 1998; Karanci et al. 2005; Barberi et al. 2008; Miceli et al. 2008; Armaş and Avram 2009; Kellens et al. 2011).

2. Level of education Education is also frequently found to be significant in explaining perceptions of risks (Karanci et al. 2005; Barberi et al. 2008), with those with lower levels of qualifications usually having greater perception of risk (Armaş and Avram 2009).

3. Age Many studies explore the influence of age, often finding that older people have a higher perception of risk (Kellens et al. 2011), however, this is usually a weaker relationship than with other socio-demographic variables (e.g. Karanci et al. 2005; Lindell and Hwang 2008; Miceli et al. 2008).

\section{Sampling regime}

To reduce the biases associated with each in isolation, survey responses were gathered by three methods between July 2014 and February 2015. First, passersby in Truro city centre, one of the largest urban areas in Cornwall, were asked to participate. Participants were selected at random and those who did not have time to complete the survey were given a flyer promoting the online version. Second, a press release was issued advertising the online version of the survey, in which INNP were not mentioned to avoid creating a bias in participants. Third, participants identified as likely to come across Japanese knotweed in their occupation through online searches (e.g. estate agents) and through email distribution lists, were emailed the link to the online survey. All participants were Cornwall residents.

\section{Survey design}

The survey was designed following guidance from Bernard (2011). All questions analysed here were closed, response options to which were randomised where possible. The survey was piloted several times to refine wording and order of questions.
There were three sections in the survey (see Appendix S1 in Supplementary Information for full list of questions). The first asked about perception of risk of Japanese knotweed, split into two questions addressing (1) perception of frequency, and (2) perception of severity of impacts. To put this into context, questions were also asked about perception of risk of other potential concerns on domestic property: ivy (Hedera helix), large trees close to the property, gulls, bats, subsidence, damp, flooding, dry rot, mundic (deterioration of concrete structures due to inappropriate materials used), and radon (a natural gas which can have elevated levels inside some buildings and has associated health concerns). These potential concerns were derived from semi-structured interviews with estate agents (see Appendix S2 for details).

The second section focused solely on Japanese knotweed. Participants were asked if they had heard of this INNP. If they answered no, they moved straight to the final section. Questions were asked to determine if participants had had Japanese knotweed on a property they owned or rented, or on land they managed (direct domestic experience). Then two questions were asked to explore perceptions of particular risks (these were compiled based on results from analysis of internet discourse on the subject and semi-structured interviews with housing market professionals, see S2 for details). The questions were (a) 'what is your perception of the threat posed by the following issues associated with Japanese knotweed in domestic gardens?' And (b) 'what would be your primary motivation for taking action to control Japanese knotweed if present in the garden where you currently live?'.

The third section collected background data, including socio-demographics (age, gender, level of education), and asked questions that allowed us to identify whether participants worked in an occupation where they regularly came across Japanese knotweed (direct professional experience).

The sample comprised a marginally lower percentage of women than in the region (49.2 and 51.6\% respectively; ONS 2011; Table S1). It comprised similar percentages to the region in all age categories: 18-29 age category was 18.5 and $20.7 \%$ respectively, 30-39 age category was 18.8 and $16.9 \%$ respectively, 40-49 age category was 19.5 and $18.6 \%$ respectively, 50-59 age category was 18.8 and $15.4 \%$ respectively, and the $60+$ age category was 24.3 and $28.5 \%$ respectively (ONS 2011). The percentage of 
participants with the top level of education (first degree or above) was higher than for the region (52.9\% and 26\% respectively; ONS 2011). This was skewed by the targeting of participants with professional experience in the housing market and in ecology. A similar percentage of the sample owned property compared with the region $(67.2 \%$ and $69.6 \%$ respectively; ONS 2011).

\section{Analysis}

We first determined which drivers predicted perception of risk of Japanese knotweed in domestic gardens. Two models were constructed (using R 3.1.3; R Core Team 2015) to evaluate the responses to the following questions (1) 'how frequently do you think the following occur on domestic properties in Cornwall?', (2) 'if the following were identified on a property, how severe do you think the consequences could be?'. For each question participants could choose from five levels of response or respond 'no idea/never heard of'. Responses of the last option were excluded from analyses. Explanatory variables included in the maximal models were direct professional experience of Japanese knotweed (three-level fixed factor), direct domestic experience of Japanese knotweed (two-level fixed factor), indirect experience of Japanese knotweed (two-level fixed factor), increased perceived geographical proximity to risk (two-level fixed factor), increased proximity to liability of risk, (two-level fixed factor), age category (five-level fixed factor), education (four-level fixed factor) and gender (twolevel fixed factor; Table 1). As the response variable was categorical we used cumulative link models using the 'clm' function in the 'ordinal' package (Christensen 2014). Cumulative link models, also known as ordered regression models or proportional odds models, employ a modified Newton-Raphson algorithm to provide accurate maximum likelihood estimates of the parameters (Christensen 2014). To verify whether model results were not due to differences in occupation, models with only participants whose occupation did not involve Japanese knotweed were also constructed.

Following a multi-model inference approach (Grueber et al. 2011) we used the 'MuMin' package (Barton 2011) to determine the final averaged model and to evaluate the relative importance of each parameter. We used the natural averaging method
(Burnham and Anderson 2002). All models where $\Delta$ AIC $<2$ were used to produce the averaged model (Burnham and Anderson 2001).

We were particularly interested in how direct professional experience of Japanese knotweed influenced perception of risk, as it has been found to be a significant driver explaining perception of INNP more generally (Selge et al. 2011; Gozlan et al. 2013). To address this, we explored whether sub-categories differed in (1) perception of risk relative to other risks on domestic property, and (2) which specific risks concern them most. Averages, standard errors and rankings were calculated for (a) each potential risk on domestic property (again, 'no idea/never heard of' responses excluded) and for (b) participants' perception of the threat to particular risks from Japanese knotweed ('no idea' responses excluded). The number of participants within each sub-category of direct professional experience (other, housing market and ecology) who listed a particular risk as their primary motivation for taking action to control Japanese knotweed were summed and ranks were calculated.

\section{Results}

In total 329 surveys were completed (144 in person, 185 online).

\section{Drivers of perception of risk}

Participants perceived Japanese knotweed to be less frequent on domestic property in Cornwall if their occupation involved the housing market (estimate $=-1.707 \pm 0.331(\mathrm{SE}), p<0.001)$, if they did not have domestic experience of Japanese knotweed (estimate $=0.907 \pm 0.327(\mathrm{SE}), p=0.006)$, if they did not know of Japanese knotweed within $5 \mathrm{~km}$ of their home (estimate $=0.686 \pm 0.228$ (SE), $p=0.003)$, or if they had the top level of education (1st degree or above; estimate $=-0.973 \pm 0.327$ (SE), $p=0.003$; Table 2; see Table S2 for global models and S3 for top models). Education remained significant in the model that only carried out analysis of participants whose profession was 'other' (see Table S4 for details).

Participants who thought that the consequences of Japanese knotweed being present on domestic property could be more severe had occupations that involved the 
Table 2 Top candidate models and model averaged parameter estimates from the top models of cumulative linkmodels exploring the effect of every combination of explanatory factors for (a) how frequently people thought Japanese knotweed occurred on domestic property in Cornwall and (b) how severe people thought the consequences of having Japanese knotweed on domestic property in Cornwall could be

\begin{tabular}{|c|c|c|c|c|c|c|}
\hline & Estimate & $\begin{array}{l}\text { Std. } \\
\text { Error }\end{array}$ & $\begin{array}{l}\text { Lower } \\
\text { CI }\end{array}$ & $\begin{array}{l}\text { Upper } \\
\text { CI }\end{array}$ & Significance & RIV \\
\hline \multicolumn{7}{|l|}{ (a) } \\
\hline 112 & -3.703 & 0.415 & -4.519 & -2.887 & $* * *$ & \\
\hline 213 & -2.023 & 0.355 & -2.721 & -1.324 & $* * *$ & \\
\hline 314 & -0.071 & 0.333 & -0.726 & 0.585 & & \\
\hline $4 \mid 5$ & 1.524 & 0.347 & 0.840 & 2.208 & $* * *$ & \\
\hline Direct professional experience (occupation involves ecology) & -0.399 & 0.306 & -1.001 & 0.203 & & 1 \\
\hline $\begin{array}{l}\text { Direct professional experience (occupation involves housing } \\
\text { market) }\end{array}$ & -1.707 & 0.331 & -2.358 & -1.056 & $* * *$ & \\
\hline Direct domestic experience (true) & 0.907 & 0.327 & 0.264 & 1.551 & $* *$ & 1 \\
\hline Indirect experience: if heard only from mass media (true) & -0.408 & 0.348 & -1.094 & 0.278 & & 0.4 \\
\hline Proximity to risk: if own property (yes) & -0.113 & 0.254 & -0.613 & 0.386 & & 0.1 \\
\hline Proximity to risk: know Japanese knotweed within $5 \mathrm{~km}$ (true) & 0.686 & 0.228 & 0.237 & 1.135 & $* *$ & 1 \\
\hline Gender (male) & -0.343 & 0.223 & -0.782 & 0.096 & & 0.6 \\
\hline Education (level 2) & -0.649 & 0.468 & -1.569 & 0.272 & & 1 \\
\hline Education (level 3) & -0.706 & 0.375 & -1.444 & 0.031 & & \\
\hline Education (level 4) & -0.973 & 0.327 & -1.617 & -0.329 & $* *$ & \\
\hline \multicolumn{7}{|l|}{ (b) } \\
\hline $1 \mid 2$ & -1.732 & 0.424 & 0.425 & 4.074 & $* * *$ & \\
\hline 213 & 0.018 & 0.383 & 0.384 & 0.047 & & \\
\hline 314 & 1.262 & 0.395 & 0.396 & 3.187 & $* *$ & \\
\hline 415 & 2.350 & 0.414 & 0.416 & 5.655 & $* * *$ & \\
\hline Direct professional experience (occupation involves ecology) & 0.446 & 0.317 & 0.319 & 1.401 & & 0.9 \\
\hline $\begin{array}{l}\text { Direct professional experience (occupation involves housing } \\
\text { market) }\end{array}$ & 0.759 & 0.318 & 0.319 & 2.377 & $*$ & \\
\hline Direct domestic experience (true) & 0.328 & 0.319 & 0.320 & 1.024 & & 0.2 \\
\hline Indirect experience: if heard only from mass media (true) & 0.610 & 0.340 & 0.341 & 1.787 & & 0.7 \\
\hline Proximity to risk: if own property (yes) & 0.502 & 0.252 & 0.253 & 1.980 & $*$ & 0.7 \\
\hline Proximity to risk: know Japanese knotweed within $5 \mathrm{~km}$ (true) & 1.198 & 0.235 & 0.235 & 5.090 & $* * *$ & 1 \\
\hline Gender (male) & -0.368 & 0.227 & 0.228 & 1.614 & & 0.6 \\
\hline Education (level 2) & -0.217 & 0.436 & 0.438 & 0.495 & & 0.6 \\
\hline Education (level 3) & 0.670 & 0.375 & 0.376 & 1.780 & & \\
\hline Education (level 4) & -0.071 & 0.319 & 0.320 & 0.223 & & \\
\hline Age (30-39) & 0.739 & 0.361 & 0.363 & 2.036 & $*$ & 0.2 \\
\hline Age (40-49) & 0.760 & 0.361 & 0.362 & 2.097 & $*$ & \\
\hline Age (50-59) & 0.800 & 0.375 & 0.376 & 2.125 & $*$ & \\
\hline Age $(60+)$ & 1.169 & 0.370 & 0.371 & 3.148 & $* *$ & \\
\hline
\end{tabular}

Lower CI lower confidence interval, Upper CI Upper confidence interval, RIV is the relative variable importance, which is the summed weight of all models with a $\triangle \mathrm{AICc}<2$ that contain the variable of interest

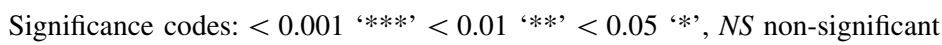


housing market (estimate $=0.759 \pm 0.318$ (SE), $p=0.017$ ), knew of Japanese knotweed within $5 \mathrm{~km}$ of their home (estimate $=1.198 \pm 0.235(\mathrm{SE}), p<$ 0.001 ), or were older ('30-39' estimate $=0.739 \pm$ 0.361 (SE), $p=0.041 ;$; 40-49' estimate $=0.760 \pm$ $0.361 ; \quad p=0.036 ; \quad$ '50-59' estimate $=0.800 \pm$ $0.375, p=0.034 ;$ ' $60+$ ' estimate $=1.076 \pm 0.39$ (SE), $p=0.002$; Table 2; see Appendix S2 for global models and $\mathrm{S} 3$ for top models). If participants owned property was also significant in the model, but only marginally (estimate $=0.502 \pm 0.252 \quad(\mathrm{SE}), \quad p=$ 0.048). The third level of education ("further education or vocational training') was marginally significant in the global model, however, it was not significant in the averaged model or when a model was constructed using only participants whose occupation was 'other' (see Table S4 for details).

Participants whose occupation was 'other' ranked their perception of how frequently Japanese knotweed occurs on domestic property in Cornwall as highest (6th) in relation to the other potential concerns on domestic property, followed by participants whose occupation involved the housing market (6th), and participants whose occupation involved ecology ranked it lower (11th; Fig. 1a). Both participants whose occupation involved the housing market and ecology ranked the potential severity of Japanese knotweed on domestic property higher (4th) in relation to other potential threats, whereas participants whose occupation was 'other' ranked Japanese knotweed lower (7th; Fig. 1b).

\section{Risks of greatest concern to participants}

The most common primary motivation given to control Japanese knotweed in domestic gardens by participants whose occupation was 'other', or involved ecology, was the potential for it to spread to adjacent land, whereas this ranked second for participants whose occupation involved the housing market (Table 3). Participants whose occupation involved the housing market reported their primary motivation to be concern about damage to building structure, which was ranked second by participants whose occupation was 'other', and third by participants whose occupation involved ecology.

Participants whose occupation was 'other', housing market and ecology all ranked their perception of the
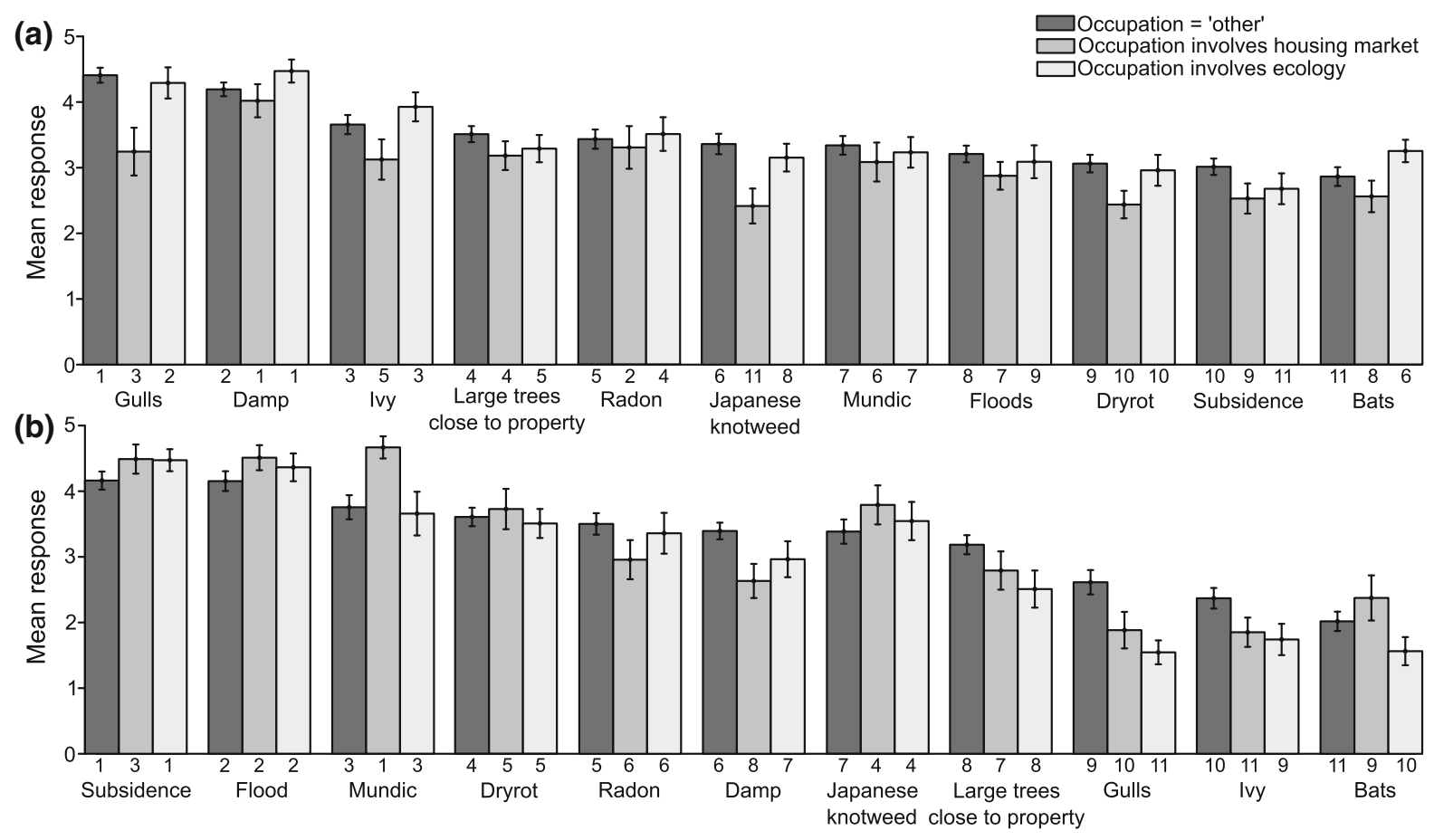

Fig. 1 Participants' responses to a how frequently people thought certain issues occurred on domestic property in Cornwall and $\mathbf{b}$ how severe people thought the consequences of having these issues on domestic property in Cornwall could be. Response 'no idea/never heard of' excluded. Numbers represent the rank 
Table 3 Response to the question: "What would be your primary motivation for taking action to control Japanese knotweed if present in the garden where you currently live?' (Participants could only select one answer)

\begin{tabular}{|c|c|c|c|c|c|c|}
\hline Primary motivation & Occupation $=$ other & Rank & $\begin{array}{l}\text { Occupation involved } \\
\text { housing market }\end{array}$ & Rank & $\begin{array}{l}\text { Occupation involved } \\
\text { ecology }\end{array}$ & Rank \\
\hline $\begin{array}{l}\text { Concern it will spread to adjacent } \\
\text { land }\end{array}$ & 63 & 1 & 12 & 2 & 20 & 1 \\
\hline $\begin{array}{l}\text { Concern about damage to structure } \\
\text { of the house }\end{array}$ & 38 & 2 & 13 & 1 & 8 & 3 \\
\hline $\begin{array}{l}\text { Concern about negative impacts on } \\
\text { other plants }\end{array}$ & 38 & 2 & 2 & 6 & 9 & 2 \\
\hline $\begin{array}{l}\text { Concern it will devalue the } \\
\text { property }\end{array}$ & 18 & 4 & 10 & 3 & 5 & 5 \\
\hline $\begin{array}{l}\text { Concern about potential future } \\
\text { expenses }\end{array}$ & 10 & 6 & 4 & 4 & 6 & 4 \\
\hline $\begin{array}{l}\text { Concern about damage to structure } \\
\text { of the garden }\end{array}$ & 12 & 5 & 2 & 6 & 2 & 6 \\
\hline $\begin{array}{l}\text { Concern about negative impacts on } \\
\text { animals }\end{array}$ & 9 & 7 & 0 & 9 & 2 & 6 \\
\hline Other & 5 & 9 & 3 & 5 & 2 & 6 \\
\hline $\begin{array}{l}\text { I would have no motivation to take } \\
\text { action }\end{array}$ & 6 & 8 & 2 & 6 & 0 & 9 \\
\hline It looks unsightly & 2 & 10 & 0 & 9 & 0 & 9 \\
\hline
\end{tabular}

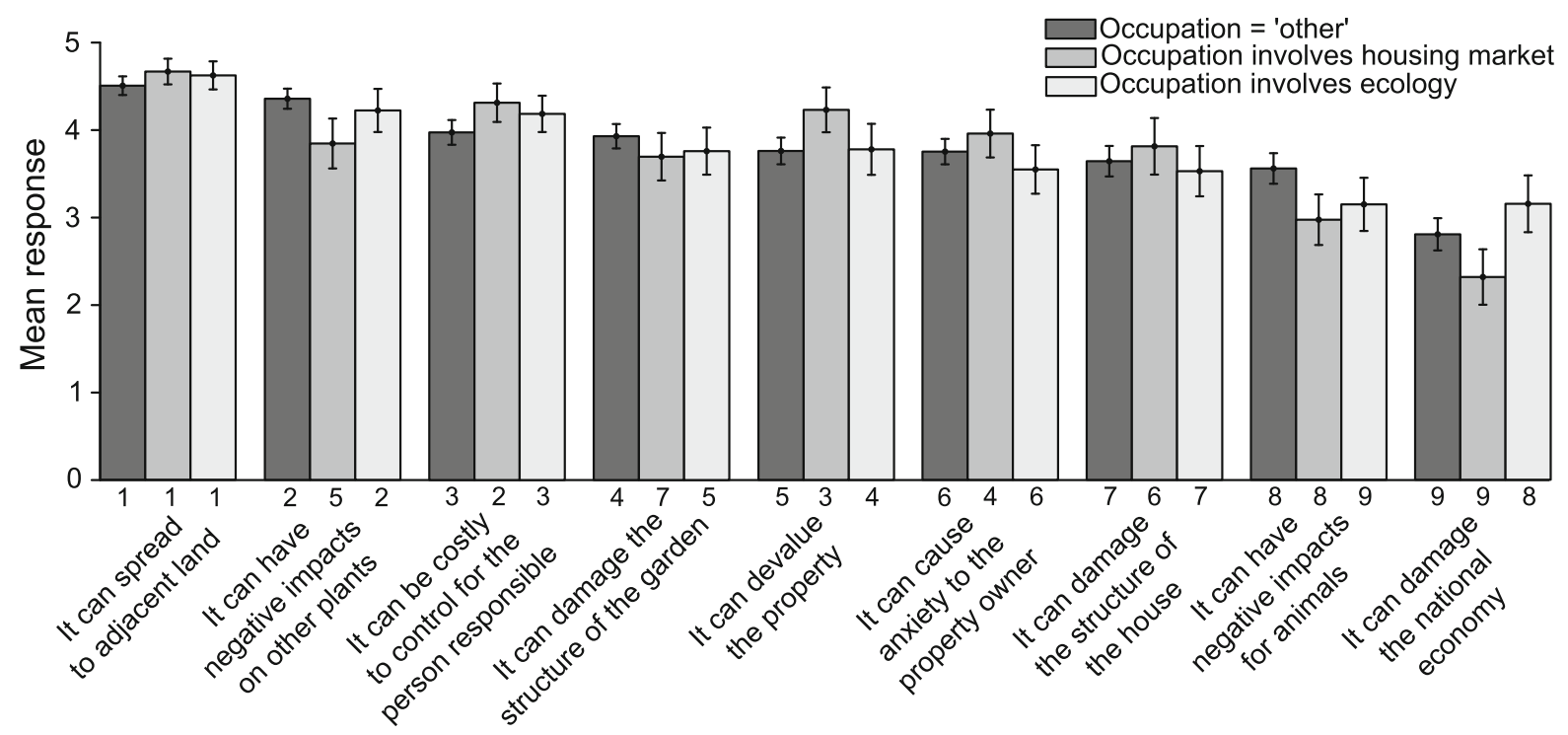

Fig. 2 Survey participants' response to the question 'What is your perception of the threat posed by the following issues associated with Japanese knotweed in domestic gardens?' Response 'no idea' excluded. Numbers represent the rank

threat by Japanese knotweed spreading to adjacent property as the highest (Fig. 2). Perceptions about the level of threat from other potential risks of 'devaluing property' and damage to the structure of the property were ranked much lower by all participants.

\section{Discussion}

This study asked the questions: what are the drivers of people's perception of the risks from INNP in domestic gardens, and which risks concern them 
most? Japanese knotweed in the UK was used as a case study. We found large differences in perceived risk of Japanese knotweed depending on people's profession, their direct domestic experience, their perceived geographical proximity to the risk, and socio-demographic differences. Here we consider explanations for these results and discuss the implications for garden management decisions, policy, risk communication, and awareness strategies.

\section{Drivers of perception of risk}

Direct professional experience was significant in predicting perception of the frequency of Japanese knotweed on domestic property, as well as perception of the potential severity of the consequences. Participants whose occupation involved the housing market perceived the frequency of Japanese knotweed on domestic property as lowest, but perceived the potential severity of the consequences as highest. Housing market professionals are likely to encounter Japanese knotweed on domestic properties if it is present, and therefore are likely to have more accurate knowledge of the frequency with which it occurs therein than other participant groups. This increased likelihood of observing the problems that Japanese knotweed can cause in domestic gardens, including observation of particularly acute impacts, might inflate their perception of severity of risk, or alternatively might make it more accurate. The perceptions of those whose occupation involved ecology aligned more closely with participants who had no professional experience of Japanese knotweed. This might be because this subset included participants from professions that would not necessarily involve Japanese knotweed, or require knowledge about its impacts or management.

Participants with direct domestic experience of Japanese knotweed or increased perceived geographical proximity to risk, measured as whether participants knew of Japanese knotweed within $5 \mathrm{~km}$ of their home, perceived its frequency to be higher than those without these attributes. An explanation for this might be because those in these participant groups are more likely to live in areas of locally high abundance of Japanese knotweed, and therefore base their perception of frequency on their local environment. Another study found that environmental managers made decisions based on local perception of abundance and impacts of INNP (Andreu et al. 2009). If those responsible for managing domestic gardens also base management decisions regarding INNP on local frequency it perhaps means management is more appropriate for local conditions.

Our finding that the relationship between direct domestic experience and perception of severity differed to the relationship with increased perceived geographical proximity to risk, might be because observing Japanese knotweed close to home might inflate perceptions of risk due to concerns about it spreading to a respondent's property and not knowing the level of management required to control it or the reality of the severity of threat to personal property. The consequences of having direct domestic experience, however, might not be sufficiently problematic to inflate perception of risk severity. Increased research and communication about the impacts of Japanese knotweed and other INNP could help make risk perceptions more uniform.

Two socio-demographic factors were significant drivers of perception of risk. Education had a negative relationship with perception of frequency, in alignment with studies of perception of environmental risks (e.g. Armaş and Arvam 2009). Age had a positive relationship with severity of consequences, also in line with previous research exploring risk perception of environmental risks (e.g. Kellens et al. 2011). It is difficult to determine the causal mechanism underlying these relationships. Perhaps it is because with age one accumulates viewpoints about INNP, some of which may conflict and contribute to inflation of perception of risk. Alternatively, it might not be a function of age, but rather experiential and cultural differences between generations (Bremner and Park 2007). Other studies have found education and gender to influence perceptions towards INNP. For example, one study found that older people reported greater support for control and eradication of INNP in Scotland (Bremner and Park 2007). Another study found that older people, and those with higher levels of education were more supportive of higher levels of management intervention of INNP in parks (Sharp et al. 2011). Conversely, other research has found that in south-west Spain younger people were more aware of concerns surrounding INNP (García-Llorente et al. 2008). Ensuring communications about INNP are published in outlets accessible to a variety of age groups could help distribute knowledge more evenly. 
Gender was the only socio-demographic driver that was not statistically significant in predicting perception of risk of either frequency or severity. Gender may perhaps be more of a driver in emotive decisions such as control/eradication of animals, for example, lethal deer management (Dougherty et al. 2003). A study in Scotland, UK, found that men were more likely to support eradication of invasive non-native species to support conservation goals and protect rare species; however, this study does not distinguish between support for eradication of invasive non-native plants or invasive non-native animals (Bremner and Park 2007).

Additionally, whether participants had heard about Japanese knotweed only via mass media was not significant in predicting perceived frequency and at most only had a minor effect on perception of severity (see Table S4). Several studies have found a limited ability of the mass media to influence perception of other risks (Freudenburg et al. 1996; Wåhlberg and Sjöberg 2000; Brenkert-Smith et al. 2013), as well as support for management options of invasive species (Sharp et al. 2011). Despite sensationalist headlines, pictures and loaded language, factual information is contained within some articles (Freudenburg et al. 1996), which may help objectively to assess the risk. Furthermore, perhaps many doubt the credibility of some media (Sjoberg 1999), so do not base their perception of risk on it. Alternatively, it may be that other complex social processes and interactions are also producing social amplification of risk. For example, information derived through social networks (e.g. friends and family) can have a strong influence on risk perceptions of many topics including climate change (Kahan et al. 2012). To ensure accurate and useful information on invasive plants is portrayed in the media it is important authorities on invasive plants (e.g. scientists and control companies) interact regularly with the media (Barua 2010) and provide clear factual information on this topic.

\section{Risks of greatest concern to participants}

Concern about spread to adjacent land was reported as the top motivation for controlling Japanese knotweed in domestic gardens by all participant groups except those whose occupation involved the housing market, who ranked it second. Similarly, perception of the threat from Japanese knotweed spreading was ranked top by all participant groups. This is perhaps an indication of the high level of concern regarding the uncontrollability of the plant, and the consequences of not only having to control it on your land. For example, in the worst-case scenario, spread to adjacent land could result in legal proceedings (Payne and Hoxley 2012). Increased communication about practical and easy ways to stop this plant spreading could help curtail this concern, for example highlighting the need for early identification and widespread ability to identify it (Simberloff et al. 2013; Robinson et al. 2016).

Damage to the structure of a property was rated as the second highest motivation to control Japanese knotweed in a domestic garden by participants who had no professional experience of Japanese knotweed, and third by those whose occupation involved ecology. Interestingly, however, both participant groups rated their perception of risk of this threat as relatively low. A number of drivers might have influenced this. First, perhaps people perceive this threat as one they can realistically mitigate, and therefore are perhaps more likely to take preventative action if required. Second, perhaps people perceive the consequences of this threat as high, which is a reason to act to prevent it, even if the likelihood of it occurring is low. Lastly, perhaps the scientific uncertainty of this risk manifests as conflicting information, which along with variation in interpretation and communication of this risk by different secondary sources, might subsequently influence how people perceive the risk (Pidgeon et al. 2003). In-depth interviews could provide insight into why people develop the perceptions of these risks.

\section{Conclusions}

When interpreting the results of this study it is important to acknowledge that simply because a hazard is perceived to be a risk, it does not necessarily follow that the details of the risk are understood (Clayton and Myers 2009), or that perceptions logically correlate with attitudes and behaviour. There are likely to be many other drivers, such as time and money availability, impacting these complex relationships (Wåhlberg and Sjöberg 2000; Wachinger et al. 2013). The extent to which perceptions of risk are based on values influences how difficult conflicts arising from different perceptions are to resolve 
(Estévez et al. 2014). Furthermore, the lack of scientific consensus about how to control Japanese knotweed, or if it should always be controlled (Delbart et al. 2012), is likely contributing to the large variation in perceptions of risk about this plant in domestic gardens, even amongst those who encounter it in a professional context. Further research is needed to determine the actual levels of risk that Japanese knotweed poses both in urban and rural areas by quantifying its abundance and impact.

As perceptions of risk are important in determining what, if any, action is taken to manage INNP on domestic property, the results of this paper have several important implications. The results highlight the need for discourses communicating the risks of INNP in domestic gardens to be clear and accurate. This could be achieved by clarifying terminology used and concepts discussed (Selge et al. 2011), by providing balanced discussion of the risks, impacts and solutions, and highlighting the role and responsibility those managing INNP in domestic gardens have. As media publications cannot be fully regulated, it is particularly important for government organisations carefully to consider risk communication strategies. Furthermore, the drivers of risk perception identified in this study could be used to target awareness campaigns to reduce over or under-inflated risk perceptions developing. Implementation of these recommendations could help reduce the ecological and socio-economic impacts of INNP in domestic gardens, as well as the wider environment. There is a need for policy that provides support and resources for people in managing INNP in their local area (Bardsley and Edwards-Jones 2007). Although this study focused on Japanese knotweed in Cornwall, INNP in domestic gardens is a global issue, therefore applying some of the solutions discussed in this study to other countries could help reduce impacts of INNP globally.

Acknowledgements We are grateful to all those who generously gave their time to participate in the survey. This project was funded as part of the Wildlife Research CoOperative between the University of Exeter and the Animal and Plant Health Agency.

Open Access This article is distributed under the terms of the Creative Commons Attribution 4.0 International License (http:// creativecommons.org/licenses/by/4.0/), which permits unrestricted use, distribution, and reproduction in any medium, provided you give appropriate credit to the original author(s) and the source, provide a link to the Creative Commons license, and indicate if changes were made.

Author contributions All authors designed the survey, BR carried out data collection, BR and RI conducted data analysis, BR drafted the manuscript. All authors edited this and subsequent versions of the manuscript.

\section{References}

Andreu J, Vilà M, Hulme PE (2009) An assessment of stakeholder perceptions and management of noxious alien plants in Spain. Environ Manag 43:1244-1255. doi:10.1007/ s00267-009-9280-1

Armaş I, Avram E (2009) Perception of flood risk in Danube Delta, Romania. Nat Hazards 50:269-287. doi:10.1007/ s11069-008-9337-0

Banks NC, Paini DR, Bayliss KL, Hodda M (2014) The role of global trade and transport network topology in the humanmediated dispersal of alien species. Ecol Lett 18:188-199. doi:10.1111/ele.12397

Barberi F, Davis MS, Isaia R et al (2008) Volcanic risk perception in the Vesuvius population. J Volcanol Geotherm Res 172:244-258. doi:10.1016/j.jvolgeores.2007.12.011

Bardsley DK, Edwards-Jones G (2007) Invasive species policy and climate change: social perceptions of environmental change in the Mediterranean. Environ Sci Policy 10:230-242. doi:10.1016/j.envsci.2006.12.002

Barthel S, Folke C, Colding J (2010) Social-ecological memory in urban gardens - retaining the capacity for management of ecosystem services. Glob Environ Change 20:255-265. doi:10.1016/j.gloenvcha.2010.01.001

Barton K (2011) MuMIn: Multi-model inference. Version 1.0. http://cran.r-project.org/web/packages/MuMIn/index. html. Accessed 16 Sept 2015

Barua M (2010) Whose issue? Representations of human-elephant conflict in Indian and international media. Sci Commun 32:55-75. doi:10.1177/1075547009353177

Beerling DJ, Bailey JP, Conolly AP (1994) Fallopia japonica (Houtt.) Ronse Decraene. J Ecol 82:959-979. doi:10.2307/ 2261459

Bernard H (2011) Research methods in anthropology: qualitative and quantitative approaches, 5th edn. AltaMira Press, Plymouth

Bhatti M, Church A (2004) Home, the culture of nature and meanings of gardens in late modernity. Hous Stud 19:37-51. doi:10.1080/0267303042000152168

Blackburn TM, Essl F, Evans T et al (2014) A unified classification of alien species based on the magnitude of their environmental impacts. PLoS Biol 12:e1001850. doi:10. 1371/journal.pbio.1001850

Bremner A, Park K (2007) Public attitudes to the management of invasive non-native species in Scotland. Biol Conserv 139:306-314. doi:10.1016/j.biocon.2007.07.005

Brenkert-Smith H, Dickinson KL, Champ PA, Flores N (2013) Social amplification of wildfire risk: the role of social 
interactions and information sources. Risk Anal 33:800-817. doi:10.1111/j.1539-6924.2012.01917.x

Burnham KP, Anderson DR (2001) Kullback-Leibler information as a basis for strong inference in ecological studies. Wildlife Res 28:111-119. doi:10.1071/WR99107

Burnham KP, Anderson DR (2002) Model selection and multimodel inference. Springer, New York

Burningham K, Lecturer S, Fielding J, Thrush D (2008) "It'll never happen to me': understanding public awareness of local flood risk. Disasters 32:216-238. doi:10.1111/j.14677717.2007.01036.x

Carlton SJ, Jacobson SK (2013) Climate change and coastal environmental risk perceptions in Florida. J Environ Manag 130:32-39. doi:10.1016/j.jenvman.2013.08.038

Christensen R (2014) Package “ordinal”. Regression models for ordinal data. http://www.cran.r-project.org/web/packages/ ordinal/index.html. Accessed 16 Sept 2015

Clayton S, Myers G (2009) Conservation psychology: understanding and promoting human care for nature. Wiley, Chichester

Colleran BP, Goodall KE (2014) In situ growth and rapid response mmanagement of flood-dispersed Japanese knotweed (Fallopia japonica). Invasive Plant Sci Manag 7:84-92. doi:10.1614/IPSM-D-13-00027.1

Delbart E, Mahy G, Weickmans B et al (2012) Can land managers control Japanese knotweed? Lessons from control tests in Belgium. Environ Manag 50:1089-1097. doi:10. 1007/s00267-012-9945-z

Dommanget F, Evette A, Spiegelberger T, Gallet C, Pacé M, Imbert M, Navas ML (2014) Differential allelopathic effects of Japanese knotweed on willow and cottonwood cuttings used in riverbank restoration techniques. J Environ Manag 132:71-78. doi:10.1016/j.jenvman.2013.10.024

Dougherty EM, Fulton DC, Anderson DH (2003) The influence of gender on the relationships between wildlife value orientations, beliefs, and the acceptability of lethal deer control in Cuyahoga Valley National Park. Soc Nat Resour 16:603-623. doi:10.1080/08941920390201381

EA Environment Agency (2013) Managing Japanese knotweed on development sites: The knotweed code of practice. www.gov.uk/government/publications/japanese-knotweedmanaging-on-development-sites. Accessed 17 Feb 2015

Engler J, Abt K, Buhk C (2011) Seed characteristics and germination limitations in the highly invasive Fallopia japonica s.1. (Polygonaceae). Ecol Res 26:555-562. doi:10.1007/s11284-011-0813-8

Eskridge AE, Alderman DH (2010) Alien invaders, plant thugs, and the Southern curse: framing kudzu as environmental other through discourses of fear. Southeast Geo 50:110-129. doi:10.1353/sgo.0.0073

Estévez RA, Anderson CB, Pizarro JC, Burgman MA (2014) Clarifying values, risk perceptions, and attitudes to resolve or avoid social conflicts in invasive apecies management. Conserv Biol 00:1-12. doi:10.1111/cobi.12359

Fischer A, van der Wal R (2007) Invasive plant suppresses charismatic seabird - the construction of attitudes towards biodiversity management options. Biol Conserv 135:256-267. doi:10.1016/j.biocon.2006.10.026

Flynn J, Slovic P, Mertz CK (1994) Gender, race, and perception of environmental health risks. Risk Anal 14:1101-1108. doi:10.1111/j.1539-6924.1994.tb00082.x
Freudenburg WR, Lou Coleman C, Gonzales J, Helgeland C (1996) Media coverage of hazard events: analyzing the assumptions. Risk Anal 16:31-42. doi:10.1111/j.15396924.1995.tb00762.x

García-Llorente M, Martín-López B, González JA et al (2008) Social perceptions of the impacts and benefits of invasive alien species: implications for management. Biol Conserv 141:2969-2983. doi:10.1016/j.biocon.2008.09.003

Gozlan RE, Burnard D, Andreou D, Britton JR (2013) Understanding the threats posed by non-native species: public vs. conservation managers. PLoS ONE. doi:10.1371/journal. pone. 0053200

Groves R, Boden R, Lonsdale M (2005) Jumping the Garden Fence: Invasive garden plants in Australia and their environmental and agricultural impacts. CSIRO report prepared for WWF-Australia. WWF-Australia, Sydney

Grueber CE, Nakagawa S, Laws RJ, Jamieson IG (2011) Multimodel inference in ecology and evolution: challenges and solutions. J Evol Biol 24:699-711. doi:10.1111/j.14209101.2010.02210.x

Gustafson PE (1998) Gender differences in risk perception: theoretical and methodological perspectives. Risk Anal 18:805-811. doi:10.1111/j.1539-6924.1998.tb01123.x

Home Office. 2014. Reform of anti-social behaviour powers. Japanese knotweed and other invasive non-native plants. www.nonnativespecies.org/news/index.cfm?id=164. Accessed 12 on 5th oct 2014

House of Lords (2014) Infrastructure Bill. Bill 124. http:// services.parliament.uk/bills/2014-15/infrastructure.html. Accessed 15 on 21st Aug 2015

Jeschke JM, Bacher S, Blackburn TM et al (2014) Defining the impact of non-native species. Conserv Biol 28:1188-1194. doi:10.1111/cobi.12299

Kahan DM, Peters E, Wittlin M, Slovic P, Ouellette LL, Braman D, Mandel G (2012) The polarizing impact of science literacy and numeracy on perceived climate change risks. Nat Clim Change 2:732-735. doi:10.1038/nclimate1547

Karanci AN, Aksit B, Dirik G (2005) Impact of a community disaster awareness training program in Turkey: does it influence hazard-related cognitions and preparedness behaviors. Soc Behav Personal Int J 33:243-258. doi:10. 2224/sbp.2005.33.3.243

Kasperson RE, Renn O, Slovic P et al (1988) The social amplification of risk: a conceptual framework. Risk Anal 8:177-187. doi:10.1111/j.1539-6924.1988.tb01168.x

Kellens W, Zaalberg R, Neutens T et al (2011) An analysis of the public perception of flood risk on the Belgian coast. Risk Anal 31:1055-1068. doi:10.1111/j.1539-6924.2010. 01571.x

Lindell MK, Hwang SN (2008) Households' perceived personal risk and responses in a multihazard environment. Risk Anal 28:539-556. doi:10.1111/j.1539-6924.2008. 01032.x

Loram A, Tratalos J, Warren PH, Gaston KJ (2007) Urban domestic gardens $(\mathrm{X})$ : the extent \& structure of the resource in five major cities. Landsc Ecol 22:601-615. doi:10.1007/s10980-006-9051-9

Mathieu R, Freeman C, Aryal J (2007) Mapping private gardens in urban areas using object-oriented techniques and very high-resolution satellite imagery. Landsc Urban Plan 81:179-192. doi:10.1016/j.landurbplan.2006.11.009 
McDaniels TL, Axelrod LJ, Cavanagh NS, Slovic P (1997) Perception of ecological risk to water environments. Risk Anal 17:341-352

McDermott SM, Irwin RE, Taylor BW (2013) Using economic instruments to develop effective management of invasive species: insights from a bioeconomic model. Ecol Appl 23:1086-1100

McNeely JA (2001) The Great reshuffling: human dimensions of invasive alien species. IUCN, Gland and Cambridge

Miceli R, Sotgiu I, Settanni M (2008) Disaster preparedness and perception of flood risk: a study in an alpine valley in Italy. J Environ Psychol 28:164-173. doi:10.1016/j.jenvp.2007. 10.006

NBN (National Biodiversity Network). (2015). Japanese knotweed data for the UK. https://nbn.org.uk. Accessed 10 on 14th May 2015

ONS Office for National Statistics (2011) Census 2011. London, UK: ESRC/JISC. http://www.ons.gov.uk/ons/index.html. Accessed 13 Feb 2016

Payne T, Hoxley M (2012) Identifying and eradicating Japanese knotweed in the UK built environment. Struct Surv 30:24-42. doi:10.1108/02630801211226628

Pejchar L, Mooney HA (2009) Invasive species, ecosystem services and human well-being. Trends Ecol Evol 24:497-504. doi:10.1016/j.tree.2009.03.016

Pidgeon N, Kasperson RE, Slovic P (2003) The Social Amplification of Risk. Cambridge University Press, Cambridge

Qvenild M, Setten G, Skår M (2014) Politicising plants: dwelling and invasive alien species in domestic gardens in Norway. Nor Geogr Tidsskr - Nor J Geogr 68:22-33. doi:10.1080/00291951.2013.870599

R Core Team (2015) The R stats package. Version 3.4.0. https:// stat.ethz.ch/R-manual/Rdevel/library/stats/html/00Index. html. Accessed 5 July 2015

Renn O, Burns WJ, Kasperson JX et al (1992) The social amplification of risk: theoretical foundations and empirical applications. J Soc Issues 48:137-160. doi:10.1111/j.15404560.1992.tb01949.x

Restall B, Conrad E (2015) A literature review of connectedness to nature and its potential for environmental management. J Environ Manag 159:264-278. doi:10.1016/j.jenvman. 2015.05.022

RICS Royal Institution of Chartered Surveyors (2012) Japanese Knotweed and residential property, 1st edition. RICS information paper

Robinson BS, Inger R, Gaston KJ (2016) A rose by any other name: plant identification knowledge \& socio-demographics. PLoS ONE 11:1-13. doi:10.1371/journal.pone. 0156572

Selge S, Fischer A, van der Wal R (2011) Public and professional views on invasive non-native species-A qualitative social scientific investigation. Biol Conserv 144:3089-3097. doi:10.1016/j.biocon.2011.09.014

Sharp RL, Larson LR, Green GT (2011) Factors influencing public preferences for invasive alien species management. Biol Conserv 144:2097-2104. doi:10.1016/j.biocon.2011. 04.032

Shaw RH, Tanner R, Djeddour D, Cortat G (2011) Classical biological control of Fallopia japonica in the United Kingdom-lessons for Europe. Weed Res 51:552-558. doi:10.1111/j.1365-3180.2011.00880.x
Simberloff D, Martin J-L, Genovesi P et al (2013) Impacts of biological invasions: what's what and the way forward. Trends Ecol Evol 28:58-66. doi:10.1016/j.tree.2012.07. 013

Sjoberg L (1999) Risk perception by the public and by experts: a dilemma in risk management. Hum Ecol Rev 6:1-9

Slimak MW, Dietz T (2006) Personal values, beliefs, and ecological risk perception. Risk Anal 26:1689-1705. doi:10. 1111/j.1539-6924.2006.00832.x

Slovic P (1999) Trust, emotion, sex, politics, and science: surveying the risk-assessment battlefield. Risk Anal 19:689-701. doi:10.1023/a:1007041821623

Sullivan JJ, Timmins SM, Williams PA (2005) Movement of exotic plants into coastal native forests from gardens in northern New Zealand. N Z J Ecol 29:1-10

UN United Nations (2010) World urbanization prospects: the 2009 revision. Highlights: population division of the department of economic and social affairs of the United Nations Secretariat. ipcc-wg2.gov/njlite_download2.php?id = 10148. Accessed 1013 Feb 2016

Taylor SL, Dobson A, Barker K (2013) Biosecurity and the future-the impact of climate change. In: Dobson A, Barker K, Taylor SL (eds) Biosecurity, the politics of invasive species and infectious diseases. Routledge, Oxford, pp 215-229

van Ham C, Genovesi P, Scalera R (2013) Invasive alien species: the urban dimension Case studies on strengthening local action in Europe. IUCN European Union Representative Office, Brussels

van Heezik Y, Freeman C, Porter S, Dickinson KJM (2013) Garden size, householder knowledge, and socio-economic status influence plant and bird diversity at the scale of individual gardens. Ecosystems 16:1442-1454. doi:10. 1007/s10021-013-9694-8

Vanderhoeven S, Piqueray J, Halford M et al (2011) Perception and understanding of invasive alien species issues by nature conservation and horticulture professionals in Belgium. Environ Manag 47:425-442. doi:10.1007/s00267-0119621-8

Verbrugge LNH, Van den Born RJG, Lenders HJR (2013) Exploring public perception of non-native species from a visions of nature perspective. Environ Manag 52:1562-1573. doi:10.1007/s00267-013-0170-1

Vilà M, Espinar JL, Hejda M et al (2011) Ecological impacts of invasive alien plants: a meta-analysis of their effects on species, communities and ecosystems. Ecol Lett 14:702-708. doi:10.1111/j.1461-0248.2011.01628.x

Wachinger G, Renn O, Begg C, Kuhlicke C (2013) The risk perception paradox-implications for governance and communication of natural hazards. Risk Anal 33:1049-1065. doi:10.1111/j.1539-6924.2012.01942.x

Wåhlberg AAF, Sjöberg L (2000) Risk perception and the media. J Risk Res 3:31-50. doi:10.1080/136698700376699

Whitmarsh L (2008) Are flood victims more concerned about climate change than other people? The role of direct experience in risk perception and behavioural response. J Risk Res 11:351-374. doi:10.1080/13669870701552235

Zagorski T, Kirkpatrick JB, Stratford E (2004) Gardens and the bush: gardeners' attitudes, garden types and Invasives. Aust Geogr Stud 42:207-220. doi:10.1111/j.1467-8470. 2004.00260.x 